\title{
Granites and metal deposits
}

Granitic rocks, spanning a broad range of compositions and silica contents, are related genetically to a spectrum of precious-, chalcophile-and lithophile-metal deposits. The metals present are dictated by the composition, degree of fractionation and redox states of the associated intrusions. The fertile intrusions and associated metal deposits occupy many tectonic settings, but arc and back-arc environments are the most important. With the exception of some rare-metal concentrations in highly evolved granites and related pegmatites, the deposits are formed by precipitation from metal-bearing fluid that separates during magmatic crystallisation. A variety of deposit types is recognised widely. The porphyry type accounts for all of the world's molybdenum and much of the copper. Vein, skarn and carbonatereplacement types supply all the tin and tungsten, with disseminated greisens being the source for much alluvial tin. Pegmatites dominate lithium and tantalum production. Large gold deposits, the main focus of current exploration activity, include porphyry, breccia, skarn, carbonate-replacement and sheeted-stockwork vein types. Gold deposits, unlike those of other metals, appear to be products of two broad intrusive suites with different redox states, as reflected by an association with either chalcophile or lithophile metals.

\section{Introduction}

Granitic rocks (sensu lato), including associated porphyry intrusions, are related spatially, temporally and genetically to many of the world's premier metal deposits. Nearly all the world's Mo, Sn and W deposits, many rare metal ( $\mathrm{Ta}, \mathrm{Nb}, \mathrm{Li}, \mathrm{Be}, \mathrm{Zr}, \mathrm{Ga}, \mathrm{REE}$ ) deposits, more than $60 \%$ of $\mathrm{Cu}$ resources, up to $10 \%$ of $\mathrm{Fe}, \mathrm{Au}, \mathrm{Zn}, \mathrm{Pb}, \mathrm{Ag}$ and $\mathrm{U}$ as well as all or much of many minor metals ( $\mathrm{Bi}, \mathrm{Cd}, \mathrm{Sb}, \mathrm{Te}, \mathrm{Re}$, $\mathrm{In}, \mathrm{Sc}$ ) are present in and around late- to post-tectonic plutons and stocks emplaced mainly in the epizonal environment, say between one and five kilometres beneath the Earth's surface.

Furthermore, concealed granitic instrusions may have supplied metals to other ore environments, including epithermal deposits associated with subaerial volcanic rocks, volcanogenic massive sulphide deposits generated on and immediately beneath the seafloor and disseminated replacement (Carlin-type) Au deposits hosted by sedimentary rocks (Sawkins, 1990; Sillitoe, 1995). However, these three deposit types are beyond the scope of this review.

The first part of this article is a review of metal concentration processes related to granitic intrusions, including the role of magma chemistry, the tectonic settings of mineralisation, the production of

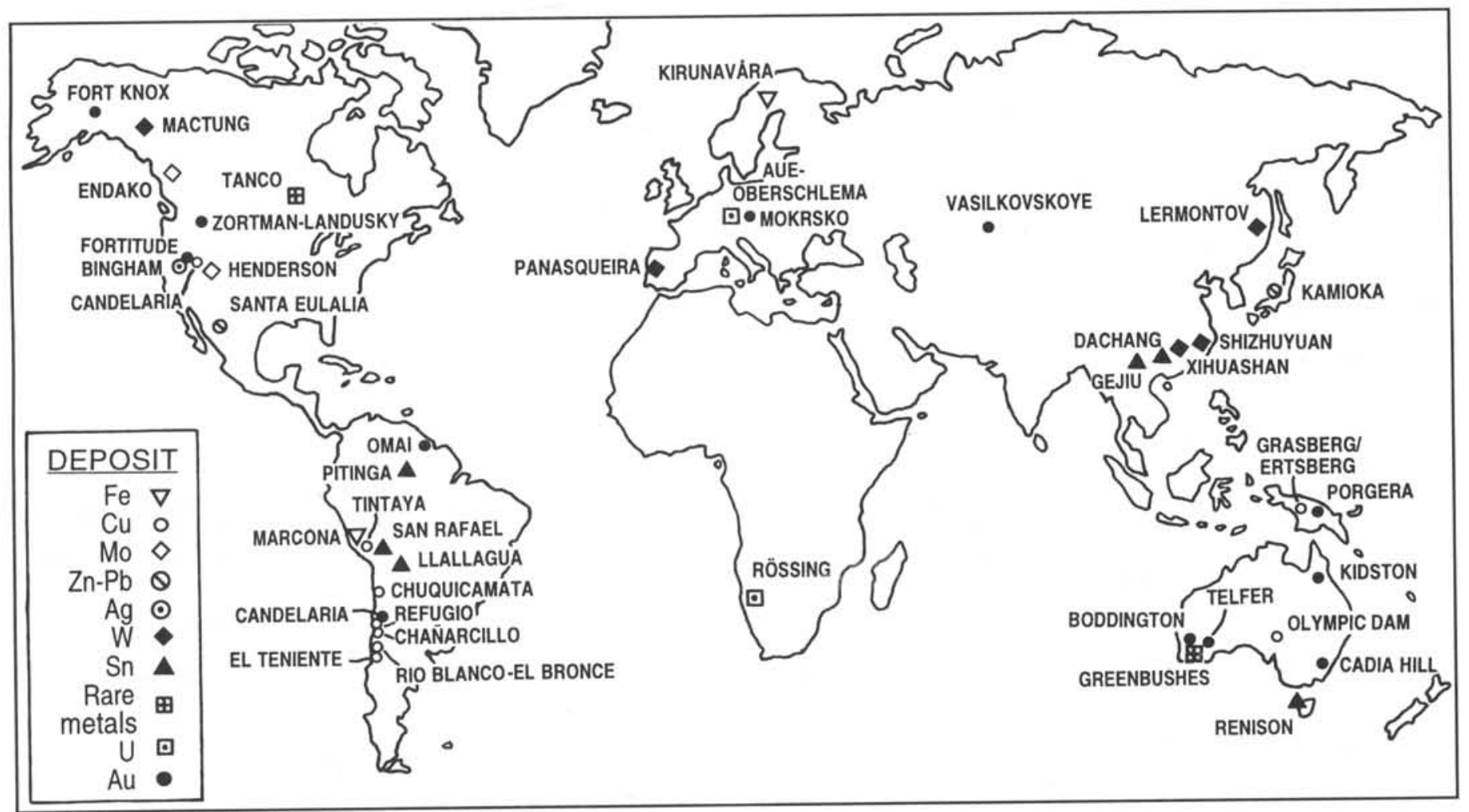

Figure 1 Locations of the granite-related metal deposits highlighted in this review. 


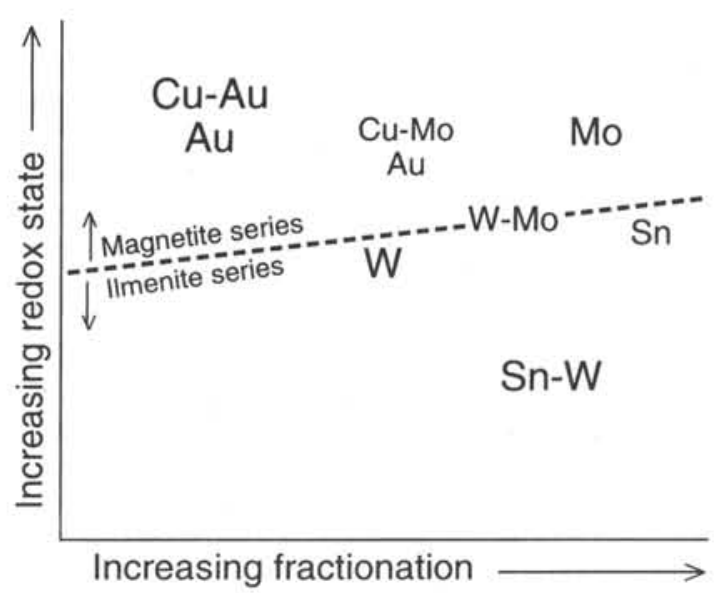

Figure 2 Diagram summarising the control of selected metal deposits by the degree of fractionation and redox state of genetically related granitic rocks. Principal and subsidiary metal concentrations are represented by large and small element symbols, respectively. Modified from Blevin and Chappell (1996).

metal-enriched magmatic fluid and the egress of this fluid to sites of metal deposition. The second part comprises a summary of major deposit types and, for each principal metal, the outstanding deposit types using world-class examples are defined (Figure 1).

\section{Magma types and corresponding metals}

Most metal deposits considered here are related to granitic rocks of low- to high-K calc-alkaline or alkaline character, which range from metaluminous to peraluminous in composition and cover a wide range of silica contents (diorite to granite, sensu stricto). The composition, degree of fractionation and redox state of magmas are the fundamental controls on the metal contents of associated ores (Figure 2; Blevin and Chappell, 1992). Fractionation in mineralised granitic suites involved a variety of igneous processes, of which fractional crystallisation seems to be the most important (Lehmann, 1993). The classification of granites into either I- and S-types, which reflects the compositions of source regions (e.g. Blevin and Chappell, 1992), or magnetite- and ilmenite-series, which describes the redox states of the rocks themselves (Ishihara, 1981), may be used as a basis for gross metallogenic subdivision. Essentially all S-type intrusions belong to the ilmenite-series, whereas I-types include both magnetite- and, less commonly, ilmenite-series rocks (Ishihara, 1981). A-type granites (Collins et al., 1982) generated lithophilemetal mineralisation, but few major deposits.

Little-fractionated I-type/magnetite-series quartz diorites, granodiorites and quartz monzonites, as well as their alkaline counterparts, may give rise to major $\mathrm{Cu}, \mathrm{Mo}$ and/or $\mathrm{Au}$ deposits. The $\mathrm{Cu} / \mathrm{Mo}$ ratio of deposits typically decreases with degree of fractionation. This reaches an extreme in the $\mathrm{Cu}$-deficient Climax-type porphyry Mo deposits, highly enriched in $\mathrm{W}, \mathrm{Sn}, \mathrm{Ta}, \mathrm{Nb}$ and $\mathrm{F}$ and associated with high-silica ( $>75 \mathrm{wt} . \%$ ) metaluminous rhyolite porphyries of alkaline parentage (Carten et al., 1993). Highly oxidised melts seem to favour hydrothermal Au concentration, although relatively reduced I-type granitic rocks appear to be associated with some deposit types (e.g. Au-rich skarns; Meinert, 1993; Figure 2). The more evolved, felsic and reduced I-type intrusions, exemplified by those in the Lachlan Fold Belt of south-eastern Australia and the Caledonian terranes of Britain, tend to be poorly mineralised.

In contrast, fractionated and relatively reduced S-type or ilmenite-series granites are associated typically with $\mathrm{Sn} \pm \mathrm{W}$ (wolframite) deposits. Blevin and Chappell (1995) emphasise, however, that Sn and W deposits may be the products of either I- or S-type granites so long as there is appreciable fractionation by plagioclase crystallisation during consolidation of the related magma suite. Extreme fractionation of either I- or S-type magmas under the influence of high volatile ( $\mathrm{F}, \mathrm{B}, \mathrm{P}$ ) contents may lead to topaz- and $\mathrm{Li}$ mica-bearing granites and granitic pegmatites that contain commercial concentrations of the rare metals.

The overall correlation between metal ratios in deposits and the compositions of their associated granitic rocks provides strong evidence that the magmas were the direct source of the metals, as embodied in the long-standing magmatic-hydrothermal theory of ore formation (e.g. Lindgren, 1933). The metal deposits can be generated by normal magmatic processes and, not even in the case of Sn (Lehmann, 1990), is an initially metal-enriched melt required. Nevertheless, low-order metal enrichments in magmatic source regions cannot be easily discounted and are invoked to explain the pre-eminence of some metallogenic provinces, such as those of $\mathrm{Sn}$ and $\mathrm{W}$ in southern China (e.g. Pei and Hong, 1995). A corollary of a magmatic source for metals is that ore formation does not normally result by leaching and reconcentration of metals from the host rocks of granitic intrusions by heated ground- or formation water.

Reduced intrusions favour hydrothermal concentration of Sn. which is unable to enter the magmatic sulphides and ilmenite that crystallise early in the cooling history of such magma chambers (Ishihara, 1981). In contrast, oxidised magmas inhibit magmatic sulphide precipitation and the consequent sequestration of copper and gold, which therefore remain available for partitioning into hydrothermal fluid (Candela, 1989).

\section{Tectonic settings}

The majority of granite-related metal deposits occupy arc or backarc settings, although collision and intra-plate settings are also represented (Table 1; Sawkins, 1990). Extensional regimes, or at least dilatant sites in broadly compressive settings, favour intrusion and metal concentration.

Many intrusion-related $\mathrm{Fe}, \mathrm{Cu}$ and $\mathrm{Au}$ deposits are found in Cordilleran or island arcs generated during subduction of oceanic lithosphere. Indeed, subcrustal contributions, including $\mathrm{H}_{2} \mathrm{O}, \mathrm{Cl}, \mathrm{S}$ and metals, to the parental magmas may be required for the generation of major deposits. Several large $\mathrm{Au}$ and $\mathrm{Cu}-\mathrm{Au}$ deposits in western Pacific island arcs (Table 1) and elsewhere were formed from intrusions emplaced immediately following collision events that resulted in reversals of subduction polarity and possible exten-

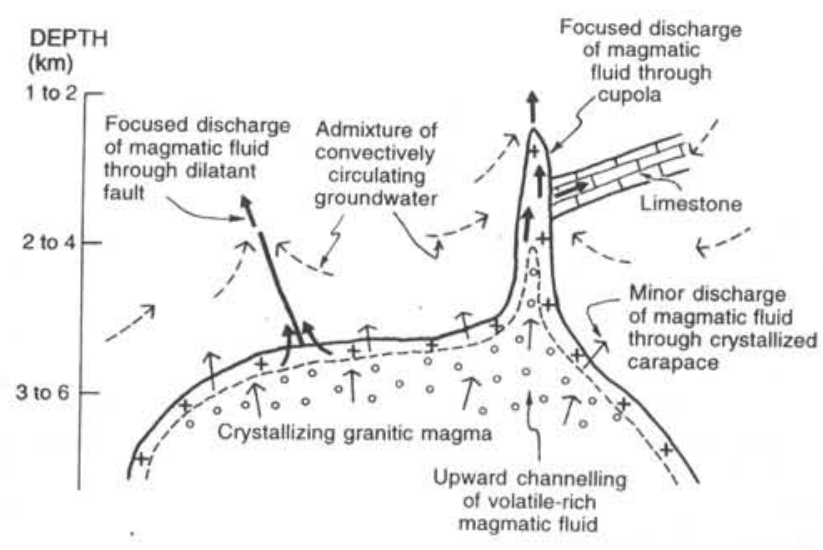

Figure 3 Schematic section to show the accumulation and focused release of magmatic fluid during crystallisation of granitic intrusions. Note the upward admixture with deeply convecting groundwater. Metal precipitation from the magmatic fluid is concentrated in the mixing zones provided by the cylindrical cupola, the reactive limestone horizon and the dilatant fault zone. 
sive partial melting of the oxidised upper parts of stalled slabs (McInnes and Cameron, 1994). Nevertheless, a few $\mathrm{Fe}$ and $\mathrm{Cu}$ deposits related to granites also formed in intra-plate extensional settings, as exemplified by Olympic Dam, South Australia (Reeve et al., 1990).

Major, granite-related $\mathrm{Zn}-\mathrm{Pb}-\mathrm{Ag}$ deposits are typically present where intrusions cut miogeoclinal sedimentary sequences along the inner sides of Cordilleran arcs. Mo $\pm \mathrm{Cu}$ deposits are also present in arc terranes, but the large Cu-deficient porphyry $\mathrm{Mo}( \pm \mathrm{W})$ deposits of Climax type were generated in back-arc environments during modest extension of continental crust (Carten et al., 1993).

Crustal contamination, deduced from such features as elevated initial $\mathrm{Sr}$ isotope ratios and inherited zircons, is more evident in granites associated with $\mathrm{Sn}, \mathrm{W}, \mathrm{U}$ and rare-metal deposits, hence their association with back-arc compressive (fold-thrust belt) settings, as in Bolivia and Peru ( $\mathrm{Sn}$ ) and the Northwest Territories-Yukon in Canada (W), or zones of continental collision, as in the Hercynian belt of Europe ( $\mathrm{Sn}, \mathrm{U})$, southern China $(\mathrm{Sn}, \mathrm{W})$ and the Damara belt of Namibia (U). Intra-plate granitic magmatism, triggered by mantle plume activity, as in Brazil and Nigeria, is also associated with lithophile-element mineralisation.

\section{Metal concentration}

Generally, the extraction of metals and other clements from magmas takes place by means of exsolution of an aqueous fluid phase. Exceptions are some of the rare metals, especially $\mathrm{Ta}$ and $\mathrm{Li}$, which attain commercial concentrations by direct crystallisation of minerals from highly evolved meits (Cerny, 1991; Pollard, 1995). The transport efficiency of most metals is controlled by the chloride content of the fluid phase because the metals concerned are complexed with chloride ions. The likely exceptions are $\mathrm{W}$ and Mo, transported as hydroxyacid complexes. Partitioning of metals, such as $\mathrm{Cu}$, into a magmatic fluid (both vapour and hypersaline liquid) is most efficient at shallow crustal depths, say $3-4 \mathrm{~km}$, from wet magmas with high $\mathrm{Cl} / \mathrm{H}_{2} \mathrm{O}$ ratios (Candela and Piccoli, 1995).

In order for a metal deposit to form in or around the apical parts of a granite pluton, metal-bearing fluid must first undergo concentration in the upper parts of the chamber, possibly by processes such as convective overturn and side-wall crystallisation. Fluid introduction also may result from intrusion of mafic magma into the lower parts of felsic chambers (e.g. Carten et al., 1993). The fluid then must be channelled upwards effectively through the magma column (Figure 3 ). This requires permeability in the crystallising magma chamber, which is favoured by high initial water and other volatile concentrations, low degrees of crystallisation and low pressures, i. e. shallow depths (Candela, 1991). Intrusive contacts, faults and permeable lithologies are effective in focusing the ascent of the magmatic fluid beyond the magma chamber (Figure 3 ).

Some of the melt and fluid are vented from the parent magma chambers through cupolas, which in porphyry systems commonly have the form of steep cylinders that are taller $(>2 \mathrm{~km})$ than they are wide. Magma chambers with volumes as small as $15 \mathrm{~km}^{3}$ are estimated to liberate sufficient magmatic fluid to generate moderatesised porphyry $\mathrm{Cu}$ deposits in their cupolas (Cline, 1995), although initial magma volumes some 20-times greater are believed to be required to generate a Sn deposit (Lehmann, 1990). Major metal deposits are favoured by the focused ascent of fluid through one or a few cupolas (Figure 3). Quenching of magma in these cupolas gives rise to the development of the characteristic porphyry texture (Burnham, 1979). Release of mechanical energy during escape of fluid generates fracture networks, including hydrothermal breccias, which provide sites for metal deposition (Burnham, 1979).

Metal deposition, in the form of sulphides ( $\mathrm{Cu}, \mathrm{Mo}, \mathrm{Pb}, \mathrm{Zn}, \mathrm{Ag}$, $\mathrm{Bi}, \mathrm{Sb}$ ), oxides (Fe, Sn, W), fluorcarbonate (REE) or native metal (Au), is caused by destabilisation of their aqueous, most commonly chloride complexes. Destabilisation is induced by cooling, reaction with rock in or around the cupola and, in particular, mixing with

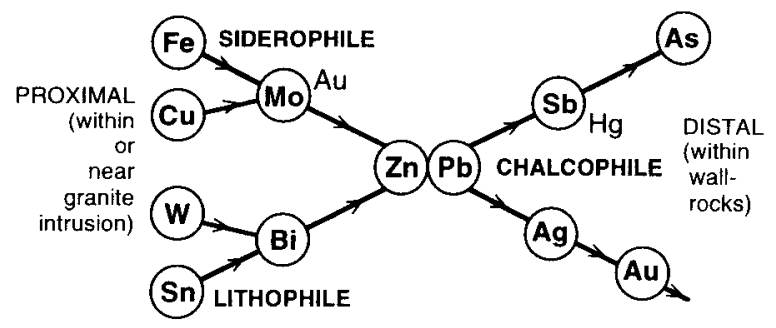

Figure 4 Schematic representation of the two principal metal zoning sequences, siderophile to chalcophile and lithophile to chalcophile, displayed by ore deposits and districts related genetically to granitic intrusions. $Z n$ and $P b$ are present in both sequences, as emphasised schematically by the cross-over point. Modified from Rundquist (1982).

marginal groundwater (Figure 3; Burnham, 1979). Sequential precipitation of metals gives rise to zoning at the deposit and district scales (Emmons, 1927). Examples include: outward increases in $\mathrm{Mo} / \mathrm{Cu}$ and $\mathrm{Mo} / \mathrm{Au}$ and upward decreases in $\mathrm{Au} / \mathrm{Cu}$ in many $\mathrm{Au}$-rich porphyry $\mathrm{Cu}$ deposits (Sillitoe, 1993); and $\mathrm{Zn}-\mathrm{Pb} \pm \mathrm{Ag}$ concentrations on the peripheries of $\mathrm{Cu}, \mathrm{Mo}, \mathrm{W}$ and $\mathrm{Sn}$ deposits and districts (Figure 4; Rundquist, 1982).

Studies of primary fluid inclusions in quartz and associated minerals from granite-related ore deposits reveal that most of the metals were introduced as components of $\mathrm{Na}-, \mathrm{K}$ - and Ca-rich chloride brines at temperatures in the $550-300^{\circ} \mathrm{C}$ range, with more dilute and cooler fluids generally being responsible only for late and peripheral mineralisation stages (Roedder, 1984). Microanalysis reveals that the hypersaline liquid contains several hundred to thousands of ppm of the ore metals (Heinrich et al., 1992; Bodnar, 1995). Oxygen and $\mathrm{H}$ isotopic studies confirm that the early fluids were magmatically derived, whereas the later fluids in the shallower and more distal parts of deposits or districts show evidence for mixing of the magmatic component with up to $50 \%$ groundwater (Taylor, 1979).

\section{Deposit types}

Most intrusion-related metal deposits generated from magmatic fluid can be assigned to six broad types, which may occur alone or in various combinations. The largest of these deposits, attaining several thousand million tonnes, are of the porphyry type, whereas the smallest, normally less than ten million tonnes, are veins. Large, skarn, carbonate-replacement, greisen and breccia-hosted deposits are typically of intermediate sizes.

Porphyry deposits, containing mainly $\mathrm{Cu}$, Mo and/or $\mathrm{Au}$, are centred on cylindrical porphyry stocks, from less than $100 \mathrm{~m}$ to several kilometres in diameter-the cupolas on the tops of granitic plutons (Figure 5). The stocks are multi-phase in character, with the highest grade ore being hosted by early, commonly the earliest, porphyry intrusions and, in some deposits, also by the wallrocks. Less well-mineralised porphyries intrude during and after the main alteration and metal introduction events (Figure 5; Gustafson and Hunt, 1975; Carten et al., 1988; Sillitoe, 1993). Much of the metal in porphyry deposits occurs in multi-directional stockwork sulphide \pm quartz veinlets that accompany $\mathrm{K}$-silicate alteration, typified by post-magmatic biotite and K-feldspar. Sericitic alteration, defined by quartz, sericite and pyrite, commonly overprints all or parts of K-silicate zones and, in many cases, gives rise to partial or complete removal of metals.

Skarn deposits develop by conversion mainly of carbonate rocks to metal-bearing calcic or magnesian silicate assemblages alongside or near granitic intrusions. The intrusions may host porphyry deposits (Figure 5) or be largely unmineralised (Figure 7). Early prograde silicate assemblages, principally garnet and pyroxene in calcic systems, are normally deficient in metals, whereas later ret- 


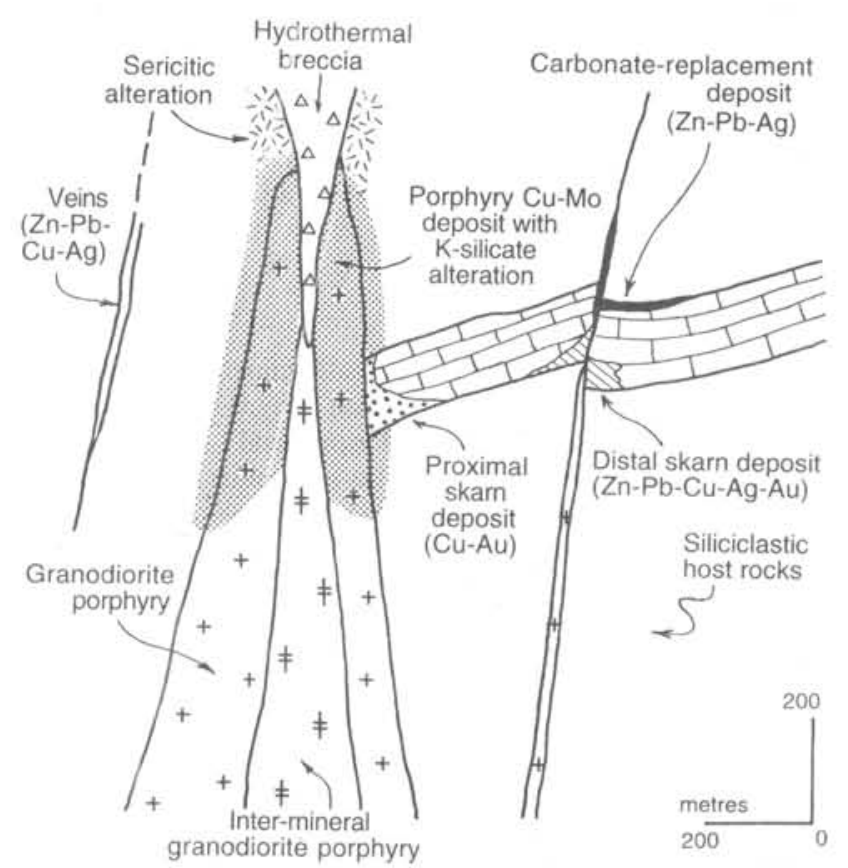

Figure 5 Schematic section to show spatial inter-relationships between porphyry $\mathrm{Cu}$, skarn, carbonate-replacement, breccia and vein deposits in and around a porphyry cupola above a granitic pluton. All the deposit types do not necessarily occur in a single system.

rograde stages introduce most of the metals in conjunction with hydrous assemblages containing such minerals as actinolite, biotite, muscovite, chlorite, talc, quartz and carbonates (Einaudi et al.. 1981). All metals concentrated by magmatic fluid are found in skarn deposits. Skarn deposits are localised by combinations of favourable lithologies and faults, and therefore commonly are stratabound, but partially vein- and fracture-controlled.

Carbonate-replacement deposits are generated where carbonate rocks beyond the skarn front interact with diluted magmatic fluid, the host limestone or marble being replaced directly by semi-massive to massive sulphides. Tin (Figure 6) and $\mathrm{Zn}-\mathrm{Pb}-\mathrm{Ag}$ (Figure 5) are commonly hosted in carbonate-replacement deposits, which may occur alone or as distal extensions to skarn bodies (Einaudi et al., 1981). Interconnected stratabound manto and steep chimney configurations typify carbonate-replacement deposits. Source intrusions commonly do not occur within $500 \mathrm{~m}$ of carbonate-replacement deposits, although porphyry dykes commonly occupy controlling faults.

Greisen deposits contain $\mathrm{Sn}$, W (as wolframite) and sometimes $\mathrm{Mo}, \mathrm{Bi}$ or $\mathrm{Be}$, accompanied by paragenetically late base metals, as disseminated mineralisation in pervasively altered cupolas and their contiguous wallrocks (Figure 6). There is commonly a close relation to quartz-dominated sheeted or stockwork vein systems (Figure 6). Greisen alteration is composed of quartz and white mica, accompanied by topaz, fluorite and/or tourmaline. Greisens display transitions to porphyry, skarn and carbonate-replacement deposits.

Breccia deposits commonly comprise vertically extensive pipes that develop either within granitic intrusions or in overlying wallrocks. Most of the ore minerals either cement the breccia clasts or impregnate breccia matrices composed of comminuted rock material. Marginal parts of breccia pipes, abutting zones of sheeted fractures, are favoured sites for ore concentration. Copper-bearing breccias occur within and around porphyry $\mathrm{Cu}$ deposits (Figure 5) or alone, but breccias also may contain one or more of the other magmatically concentrated metals (Sillitoe, 1985).

Veins are normally controlled by steep to moderately dipping faults that cut granitic intrusions and/or their wallrocks (Figures 5 and 6). Major veins extend for up to several kilometres along strike and a kilometre down dip. Veins may accompany the other deposit types, but many large ones occur alone. Historically, high-grade vein deposits were the main source of metals, such as $\mathrm{Cu}$ in northern Chile and $\mathrm{Sn}$ in Cornwall, England, but today their economic importance is diminished.

\section{Principle metal deposits}

\section{Iron}

Intrusion-related Fe deposits are dwarfed by those formed syngenetically in Precambrian banded iron formations. The largest intrusion-related deposits, consisting mainly of magnetite, may be assigned to two, possibly transitional categories: conventional skarns, such as Marcona in Peru, and igneous rock-hosted bodies, such as Kiirunavaara in Sweden (Table 1). Much discussion surrounds the origin of the latter category, although the balance of evidence seems to favour magnetite introduction by replacement rather than magmatic segregation (Hitzman et al., 1992). The igneous rock-hosted Fe deposits typically contain actinolite, with or without pyroxene, garnet and scapolite, and are accompanied by Ksilicate alteration. Albitisation is a deep, pre-ore alteration in some districts (Hitzman et al., 1992), as it is in the porphyry copper and greisen environments (e.g. Figure 6).

The igneous rock-hosted $\mathrm{Fe}$ deposits may continue their hydrothermal evolution and, given adequate $S$ availability, undergo paragenetically late additions of $\mathrm{Cu}$ and $\mathrm{Au}$ (e.g. Candelaria, Chile) and even transformation of magnetite-bearing $\mathrm{K}$-silicate assemblages to haematite-dominated sericitisation. Indeed, the haematiterich $\mathrm{Cu}-\mathrm{U}-\mathrm{Au}-\mathrm{Ag}$ breccia deposit at Olympic Dam (Table 1) is commonly considered as an end-member of this granite-related $\mathrm{Fe}$ oxide-Cu- Au clan (Hitzman et al.. 1992: Williams et al., 1995).

\section{Copper}

Intrusion-related copper deposits are dominated by those of porphyry type, the largest being the $\mathrm{Cu}-(\mathrm{Mo})$ deposits at $\mathrm{El}$ Teniente and Chuquicamata in Chile (Table 1). The latter owes its pre-eminence to the generation of supergene oxidised and enriched ores during mid-Tertiary weathering. Another extremely large porphyry

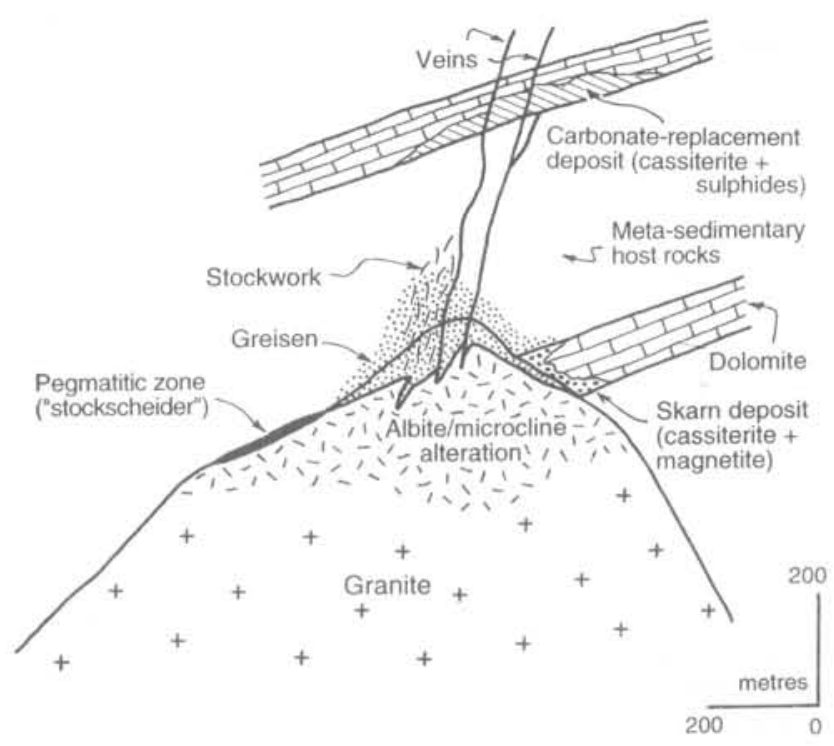

Figure 6 Schematic section to show spatial inter-relationships between greisen, skarn, carbonate-replacement, stockwork and vein deposits in a Sn-dominated system centred on a granitic cupola. All deposit types do not necessarily occur in a single system. 
$\mathrm{Cu}-(\mathrm{Mo})$ deposit, Río Blanco-Los Bronces in Chile, is dominated by a hydrothermal breccia complex that destroyed much of the preexisting stockwork mineralisation (Table 1; Serrano et al., 1996).

The only other granite-related Cu deposit that approaches the stature of the porphyry coppers is the breccia-hosted Olympic Dam deposit (Table 1; Reeve et al., 1990). Several Cu skarns, notably Tintaya in Peru and Ertsberg in Indonesia, are important economically, although they are an order of magnitude smaller than the largest porphyry $\mathrm{Cu}$ deposits.

\section{Molybdenum}

More than half the world's Mo is supplied as a by-product from porphyry $\mathrm{Cu}$ ores, mainly in the western Americas. Most of the remainder comes from porphyry Mo deposits, mainly the Henderson deposit in Colorado, USA, hosted by high-silica rhyolite porphyry and the lower-grade Endako deposit in British Columbia, Canada, hosted by quartz monzonite (Table 1).

\section{Zinc and lead}

The largest intrusion-related $\mathrm{Zn}-\mathrm{Pb}-(\mathrm{Ag})$ deposits are either calcic skarns, like Kamioka, Japan, or carbonate-replacement manto-chimney deposits like Santa Eulalia, Mexico (Table 1). In both deposit types, ore is formed distally with respect to felsic I-type intrusions, commonly in association with dykes, and shows proximal enrichment in $\mathrm{Cu}$. Nevertheless, such deposits are overshadowed by sedimentary-exhalative (sedex) $\mathrm{Zn}-\mathrm{Pb}-(\mathrm{Ag})$ deposits unrelated to magmatism.

\section{Silver}

Most of the world's Ag supply is derived as a by-product from epithermal $\mathrm{Au}$ and sedex $\mathrm{Zn}-\mathrm{Pb}$ deposits. Large granite-related deposits exploited principally for $\mathrm{Ag}$ are rare, and only Candelaria, Nevada, USA is mined currently (Table 1). Candelaria is a bulk-1onnage disseminated and stockwork deposit hosted by sedimentary rocks located distally with respect to an inferred pluton at depth (Thomson et al., 1995).

The supergene oxidised and enriched zones of vein-type $\mathrm{Ag}$ deposits, many in limestone-bearing volcano-sedimentary sequences alongside diorite or granodiorite intrusions, were exploited in Chile during the last century; the largest was Chañarcillo (Table 1).

\section{Tungsten}

Dramatic falls in the world price of $\mathrm{W}$ in the 1980 s resulted in closure of most of the western world's W mines. The largest and highest grade deposits are wolframite-dominated, greisen-bordered vein systems and scheelite-bearing calcic skarns (Table 1). The premier W skarn (and associated greisen) deposit is Shizhuyuan in Hunan province, China (Mao et al., 1995). More than $75 \%$ of the world's mined $W$ comes from numerous greisen-bordered vein deposits, notably Xihuashan, associated with S-type granites in Jiangxi province, China (Wu and Mei, 1982). Nevertheless, the extensive, shallowly dipping greisen vein system at Panasqueira, Portugal (Table 1), and the Lermontov skarn and associated greisen deposits in the Russian Far East are also current producers.

\section{Tin}

Since the 'crash' of the Sn price in 1986, only high-grade Sn deposits, besides deeply weathered elluvial, alluvial and marine placer deposits, have been commercially viable. Large, low-grade greisen and stockwork deposits have largely ceased production, although weathering of such material gave rise to a major alluvial and saprolite $\mathrm{Sn}-(\mathrm{Ta}-\mathrm{Nb})$ deposit at Pitinga in Brazil (Table 1; Horbe et al., 1991).

Currently, the major deposits are of vein type (San Rafael, Peru) and carbonate-replacement type (Dachang, Guangxi province and Gejiu, Yunnan province, China; Renison Bell in Tasmania, Australia), formed in association with either $S$ - or l-type peraluminous granites (Table 1). Nevertheless, the world's largest Sn deposit was the stockwork and vein system in subvolcanic S-type quartz latite porphyry at Llallagua, Bolivia (Sillitoe et al., 1975), which is exploited currently on only a small scale by a local mining co-operative.

\section{Rare metals}

Rare metals $( \pm \mathrm{Sn})$ are present in magmatic minerals formed as part of the crystallisation sequence, rather than as hydrothermal introductions, in some extremely fractionated topaz- and Li mica-bearing Iand S-type albite granites and granitic pegmatites. Giant Precambrian pegmatites at Greenbushes, Western Australia and Tanko, Manitoba, Canada account for much of the world's Li supply and a large share of Ta production (Table 1; Pollard, 1995).

\section{Uranium}

Vein-type U deposits, notably those of the Aue-Oberschlema district, Germany (Table 1), are widespread in and around fractionated granites. However, they are commonly formed long after magmatic fluid exsolution ceased (Table 1) because of the high hydrothermal mobility of $\mathrm{U}^{6+}$ in even low-temperature groundwater (Lehmann, 1993).

The only major intrusion-related $U$ deposit in production is Rössing, Namibia, which comprises fine-grained disseminations of mainly uraninite in S-type pegmatitic alaskite (Table 1). The alaskite is thought to be the product of anatectic melting of gneissic basement rocks (Berning, 1986). Nevertheless, the by-product pitchblende content of the Olympic Dam Cu deposit (Table 1) makes it the world's largest U resource.

\section{Gold}

Most of the premier intrusion-related Au deposits are of porphyry type (Sillitoe, 1991), and include Au-only examples like Refugio, Chile besides those containing minor (Cadia Hill, New South Wales, Australia; Boddington, Western Australia) as well as major (Grasberg, Indonesia) amounts of exploitable $\mathrm{Cu}$ (Table 1). At Boddington, an auriferous laterite, developed by Phanerozoic weathering of the porphyry-type mineralisation, is mined currently (Symons et al., 1990).

In addition, there are single major examples (Table 1) of a carbonate-replacement Au deposit at Telfer, Western Australia (Goellnicht et al., 1989), a sediment-hosted stockwork Au deposit, overprinted by high-grade, fault-controlled epithermal $\mathrm{Au}$ mineralisation, at Porgera, Papua New Guinea (Richards and Kerrich, 1993) and a sheeted-vein Au deposit at Vasilkovskoye, Kazakhstan.

The porphyry deposits, along with Telfer and Porgera, are all related to oxidised I-type intrusions of either calc-alkaline or alkaline affinity (Table 1). Other important, but smaller bulk-tonnage, intrusion-related Au deposits, like the breccia-hosted Kidston deposit in Queensland, Australia, associated with Mo-mineralised rhyolite porphyry, and the F- and Te-bearing stockwork ZortmanLandusky deposit, Montana, USA, in syenite porphyry, may also be assigned to the same oxidised I-type category.

In marked contrast, the Vasilkovskoye Au deposit (Table 1), along with other sheeted quartz vein and stockwork deposits, characterised by $\mathrm{K}$-silicate and sericitic alteration, at Mokrsko in the Czech Republic, Fort Knox in Alaska, USA and Omai in Guyana seem to be associated with somewhat more reduced. I-type, calc-alkaline to alkaline intrusions (e.g. Thompson et al., 1995; Crépeau et al., 1996). As an apparent consequence, these deposits contain $\mathrm{W}$ (as scheelite), $\mathrm{Bi}, \mathrm{As}$ and/or $\mathrm{Sb}$ rather than $\mathrm{Cu}, \mathrm{Zn}$ and/or $\mathrm{Pb}$. Moderately reduced I-type intrusions are also related to Au (-As-Bi-Te) skarns, such as Fortitude in Nevada, USA (Meincrt, 1993). 
Table 1 Selected world-class metal deposits related to granitic intrusions. (The tonnage/grade figures in column 3 refer to ore production and reserves combined)

\begin{tabular}{|c|c|c|c|c|c|c|c|c|}
\hline & $\begin{array}{l}\text { Deposit and } \\
\text { country }\end{array}$ & $\begin{array}{l}\text { Tonnage }(\mathrm{Mt}) \\
\text { and grade }\end{array}$ & $\begin{array}{l}\text { Subsidiary } \\
\text { metals }\end{array}$ & Age (Ma) & Deposit type & $\begin{array}{l}\text { Genetically } \\
\text { related intrusion }\end{array}$ & Tectonic setting & Reference \\
\hline $\mathrm{Fe}$ & $\begin{array}{l}\text { Kiirunavaara, Sweden } \\
\text { Marcona, Peru }\end{array}$ & $\begin{array}{l}2600 ; 60 \% \mathrm{Fe} \\
1600 ; 50-60 \% \mathrm{Fe}\end{array}$ & & $\begin{array}{l}1888 \pm 6 \\
137-118\end{array}$ & $\begin{array}{l}\text { Replacement (?) } \\
\text { Skarn }\end{array}$ & $\begin{array}{l}\text { I-type syenite } \\
\text { l-type granodiorite }\end{array}$ & $\begin{array}{l}\text { Arc } \\
\text { Arc }\end{array}$ & $\begin{array}{l}\text { Geijer, } 1960 \\
\text { Xie et al., } 1996\end{array}$ \\
\hline \multirow[t]{2}{*}{$\mathrm{Cu}$} & $\begin{array}{l}\text { El Teniente, Chile } \\
\text { Chuquicamata, Chile } \\
\text { Río Blanco- } \\
\quad \text { Los Bronces, Chile }\end{array}$ & $\begin{array}{l}10528 ; 1.23 \% \mathrm{Cu} \\
7239: 0.87 \% \mathrm{Cu} \\
6524 ; 0.77 \% \mathrm{Cu}\end{array}$ & $\begin{array}{l}\text { Mo } \\
\text { Mo } \\
\text { Mo }\end{array}$ & $\begin{array}{l}5 \\
34-31 \\
5\end{array}$ & $\begin{array}{l}\text { Porphyry } \\
\text { Porphyry } \\
\text { Breccia \& porphyry }\end{array}$ & $\begin{array}{l}\text { l-type dacite porphyry } \\
\text { l-type monzogranite porphyry } \\
\text { l-type quartz monzonite } \\
\text { porphyry }\end{array}$ & $\begin{array}{l}\text { Arc } \\
\text { Transpressional arc } \\
\text { Arc }\end{array}$ & $\begin{array}{l}\text { Camus, } 1975 \\
\text { Alvarez et al., } 1980 \\
\text { Serrano et al., } 1996\end{array}$ \\
\hline & $\begin{array}{l}\text { Olympic Dam, } \\
\text { Australia }\end{array}$ & $2200: 1.36 \% \mathrm{Cu}$ & U. Au, Ag, REE & $1588 \pm 4$ & Breccia & l-type syenogranite & Intra-plate rift & Reeve et al., 1990 \\
\hline Mo & $\begin{array}{l}\text { Henderson, USA } \\
\text { Endako, Canada }\end{array}$ & $\begin{array}{l}727 ; 0.17 \% \text { Mo } \\
300 ; 0.08 \% \text { Mo }\end{array}$ & & $\begin{array}{l}28 \\
142-139\end{array}$ & $\begin{array}{l}\text { Porphyry } \\
\text { Porphyry }\end{array}$ & $\begin{array}{l}\text { I-type rhyolite porphyry } \\
\text { I-type quartz monzonite }\end{array}$ & $\begin{array}{l}\text { Extensional back-arc } \\
\text { Arc }\end{array}$ & $\begin{array}{l}\text { Carten et al., } 1988 \\
\text { Bysouth \& Wong, } 1995\end{array}$ \\
\hline \multirow{2}{*}{$\mathrm{Zn-Pb}$} & $\begin{array}{l}\text { Santa Eulalia, } \\
\text { Mexico }\end{array}$ & $\begin{array}{l}37 ; 7.2 \% \mathrm{Zn} \\
8.4 \% \mathrm{~Pb}\end{array}$ & Ag. Sn. V & 27 & Carbonate replacement & I-type rhyolite (dykes) & Back-arc & Megaw, 1986 \\
\hline & Kamioka, Japan & $\begin{array}{l}90 ; 5.0 \% \mathrm{Zn} \\
0.7 \% \mathrm{~Pb}\end{array}$ & $\mathrm{Ag}$ & 65 & Skarn & l-type rhyolite porphyry & Back-arc & $\begin{array}{l}\text { Sakurai } \\
\quad \text { \& Shimazaki, } 1993\end{array}$ \\
\hline $\mathrm{Ag}$ & $\begin{array}{l}\text { Candelaria, USA } \\
\text { Chañarcillo, Chile }\end{array}$ & $\begin{array}{l}40 ; 80 \mathrm{~g} / \mathrm{t} \mathrm{Ag} \\
2 ;>3000 \mathrm{~g} / \mathrm{t} \mathrm{Ag}\end{array}$ & Au & $\begin{array}{l}193 \\
-80\end{array}$ & $\begin{array}{l}\text { Disseminated/stockwork } \\
\text { Veins }\end{array}$ & $\begin{array}{l}\text { I-type dacite (dykes) } \\
\text { I-type granodiorite }\end{array}$ & $\begin{array}{l}\text { Extensional back-arc } \\
\text { Arc }\end{array}$ & $\begin{array}{l}\text { Thomson et al., } 1995 \\
\text { Whitehead, } 1919\end{array}$ \\
\hline $\mathbf{W}$ & $\begin{array}{l}\text { Shizhuyuan, China } \\
\text { Xihuashan, China } \\
\text { Panasqueira, Portugal }\end{array}$ & $\begin{array}{l}170 ; 0.26 \% \mathrm{~W} \\
27 ; 0.48 \% \mathrm{~W}\end{array}$ & $\begin{array}{l}\text { Sn. Bi, Mo, Be } \\
\text { Sn, Bi. Mo, Be } \\
\text { Sn. Cu }\end{array}$ & $\begin{array}{l}\sim 150 \\
148-140 \\
296-292\end{array}$ & $\begin{array}{l}\text { Skarn \& greisen } \\
\text { Veins } \\
\text { Veins }\end{array}$ & $\begin{array}{l}\text { S-type granite } \\
\text { S-type granite } \\
\text { S-type granite }\end{array}$ & $\begin{array}{l}\text { Collision } \\
\text { Collision } \\
\text { Collision }\end{array}$ & $\begin{array}{l}\text { Mao et al., } 1995 \\
\text { Wu \& Mei, } 1982 \\
\text { Polya, } 1989\end{array}$ \\
\hline \multirow[t]{3}{*}{ Sn } & $\begin{array}{l}\text { Dachang, China } \\
\text { Renison Bell, } \\
\text { Australia }\end{array}$ & $\begin{array}{l}60 ; 1.0 \% \mathrm{Sn} \\
42 ; 1.0 \% \mathrm{Sn}\end{array}$ & $\mathrm{Zn}$ & $\begin{array}{l}91 \pm 2 \\
355 \pm 4\end{array}$ & $\begin{array}{l}\text { Carbonate replacement } \\
\text { Carbonate replacement }\end{array}$ & $\begin{array}{l}\text { S-type granite } \\
\text { I-type granite }\end{array}$ & $\begin{array}{l}\text { Collision } \\
\text { Collision }\end{array}$ & $\begin{array}{l}\text { Mao et al., } 1995 \\
\text { Patterson et al., } 1981\end{array}$ \\
\hline & $\begin{array}{l}\text { San Rafael, Peru } \\
\text { Llallagua, Bolivia }\end{array}$ & $\begin{array}{l}17 ; \sim 4 \% \mathrm{Sn} \\
>500000 \mathrm{Sn} \text { metal }+ \\
\sim 80 ; 0.3 \% \mathrm{Sn}\end{array}$ & $\mathrm{Cu}$ & $\begin{array}{l}24 \\
20\end{array}$ & $\begin{array}{l}\text { Veins } \\
\text { Stockwork \& veins }\end{array}$ & $\begin{array}{l}\text { S-type monzogranite } \\
\text { S-type quartz latite porphyry }\end{array}$ & $\begin{array}{l}\text { Back-arc } \\
\text { Back-arc }\end{array}$ & $\begin{array}{l}\text { Kontak et aì., } 1995 \\
\text { Sillitoe et al., } 1975\end{array}$ \\
\hline & Pitinga, Brazil & & $\mathrm{Nb}, \mathrm{Ta}$ & $1689 \pm 19$ & Disseminated & A-type peralkaline granite & Intra-plate & Horbe et al., 1991 \\
\hline \multirow[t]{2}{*}{ Li-Ta } & $\begin{array}{c}\text { Greenbushes. } \\
\text { Australia }\end{array}$ & $\begin{array}{l}33.5: 1.2 \% \mathrm{Li} \\
28.0 ; 0.04 \% \mathrm{Ta}\end{array}$ & $\mathrm{Nb}, \mathrm{Sn}$ & $2527 \pm 2$ & Pegmatite & S-type pegmatite & Greenstone belt & Partington et al., 1995 \\
\hline & Tanco, Canada & $\begin{array}{l}9.1: 1.3 \% \mathrm{Li} \\
2.1 ; 0.18 \% \mathrm{Ta}\end{array}$ & $\mathrm{Cs}$ & Archaean & Pegmatite & S-type pegmatite & Greenstone belt & Crouse et al.. 1984 \\
\hline $\mathbf{U}$ & $\begin{array}{l}\text { Rössing, Namibia } \\
\text { Aue-Oberschlema, } \\
\text { Germany }\end{array}$ & $\begin{array}{l}-370 ; 0.03 \% \mathrm{U} \\
20 ; 0.4 \% \mathrm{U}\end{array}$ & $\mathrm{Ag}, \mathrm{Co}, \mathrm{Se}$ & $\begin{array}{l}468 \pm 8 \\
\sim 300 \text { (intrusion) } \\
280-30 \text { (deposit) }\end{array}$ & $\begin{array}{l}\text { Disseminated } \\
\text { Veins }\end{array}$ & $\begin{array}{l}\text { S-type granite } \\
\text { S-type granite }\end{array}$ & $\begin{array}{l}\text { Collision } \\
\text { Collision }\end{array}$ & $\begin{array}{l}\text { Berning, } 1986 \\
\text { Schuppan et al., } 1994\end{array}$ \\
\hline \multirow[t]{4}{*}{ Au } & $\begin{array}{l}\text { Refugio, Chile } \\
\text { Cadia Hill, } \\
\text { Australia } \\
\text { Boddinoton. }\end{array}$ & $\begin{array}{l}216: 0.88 \mathrm{~g} / \mathrm{t} \mathrm{Au} \\
350: 0.64 \mathrm{~g} / \mathrm{t} \mathrm{Au}\end{array}$ & $\mathrm{Cu}, \mathrm{Mo}, \mathrm{W}$ & $\begin{array}{l}23 \\
\sim 440\end{array}$ & $\begin{array}{l}\text { Porphyry } \\
\text { Porphyry }\end{array}$ & $\begin{array}{l}\text { I-type quartz diorite porphyry } \\
\text { I-type quartz monzonite } \\
\text { porphyry }\end{array}$ & $\begin{array}{l}\text { Arc } \\
\text { Arc (post-subduction?) }\end{array}$ & $\begin{array}{l}\text { Vila \& Sillitoe, } 1991 \\
\text { Newcrest Mining } \\
\text { Staff, } 1995\end{array}$ \\
\hline & $\begin{array}{l}\text { Boddington, } \\
\text { Australia } \\
\text { Grasberg. Indonesia }\end{array}$ & $204: 1.3 \mathrm{~g} / \mathrm{t} \mathrm{Au}$ & $\mathrm{Cu}, \mathrm{Mo}, \mathrm{W}$ & $2714-2696$ & Porphyry & I-type microdiorite & Greenstone belt & Symons et al.. 1990 \\
\hline & Telfer. Australia & $62 ; 2.35$ & $\mathrm{Cu}$ & $680-620$ & Carbonate replacement & I-type granite & Intra-plate & Goellnicht et al., 1989 \\
\hline & $\begin{array}{l}\text { Porgera, Papua N G } \\
\text { Vasilkovskoye, }\end{array}$ & $\begin{array}{l}160 ; 4.7 \mathrm{~g} / \mathrm{t} \mathrm{Au} \\
100 ; 2.4 \mathrm{~g} / \mathrm{t} \mathrm{Au}\end{array}$ & $\mathrm{Ag}$ & $\begin{array}{l}6 \\
\text { Late Ordovician }\end{array}$ & $\begin{array}{l}\text { Stockwork \& vein } \\
\text { Veins \& stockwork }\end{array}$ & $\begin{array}{l}\text { I-type alkali basalt } \\
\text { I-type granodiorite }\end{array}$ & $\begin{array}{l}\text { Arc (post-collision) } \\
\text { Arc (?) }\end{array}$ & Richards \& Kerrich, 1993 \\
\hline
\end{tabular}

Kazakhstan 


\section{Conclusions}

This review demonstrates that a broad spectrum of ore deposits is a direct product of metal concentration during magmatic fractionation and ensuing hydrothermal processes. Magma chemistry, and hence the tectonic setting and source of the magma, dictate the broad metal budgets of deposits, hut do not ensure deposit formation, except in the case of a few rare-netal deposits formed directly by magmatic crystallisation. Physico-chemical processes altendant upon the exsolution and evolution of magmatic fluid control ore formation and. most importantly, the sie and metal content of the resultant deposits. Early sepatation of large volumes of magmatic fluid from shallowly emplaced, chloride-rich magma seems to lavour efficient ore genesis.

Granite-related deposits include the world's largest examples of Cu, Mo, Au. W. Sn. Ta and U besides a variety of smaller, but still important. deposits of these and other metals. The deposits range in age from Archatean to Cano/oic, although the later are more abundant (Table 1). Currently, exploration funds wortelwide are dedicated almost exclusively to the search for porphyry Cu and Cu-Au deposits and a varicty of Au deposits. including the intrusion-related lypes reviewed here. Granite-related Mo. W. Sil and U deposits are not presently the focus of explorition.

Most of these metal deposits are linked to relatively restricted ranges of intrusive compositions, with the obvious exception of Au Gold seems to adopt either a chalcophile $(\mathrm{Cu}, \mathrm{Mo} \pm 7 \mathrm{n}, \mathrm{Pb})$ or lithophile (W. Mo, Bi) association and constitutes major deposirs in or around intrusions that range from calc-alkaline rhyolite to alkaline basall-gabbro as well as possessing varied redox stalles.

\section{Acknowledgements}

Thanks are due lo Nigel Grant. Jeff Hedenguisl. Shumso Ishibara, Bernd Lehmann and Jolum Thompson for reviews and data.

\section{References}

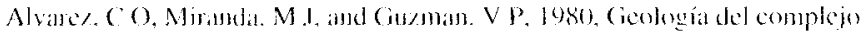

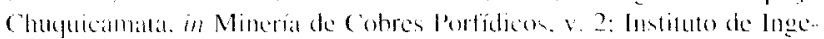

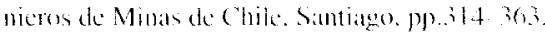

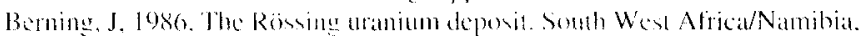

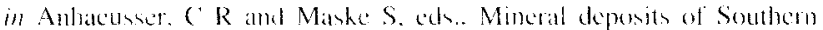

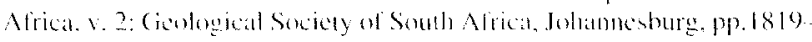
1832.

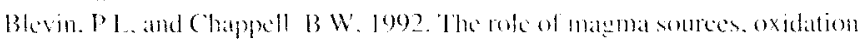

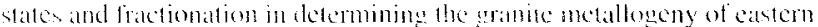

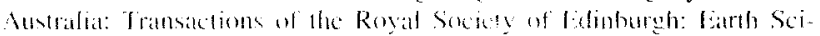
mere. 83. pp 345316

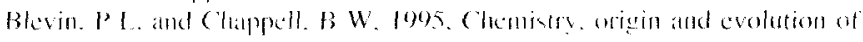

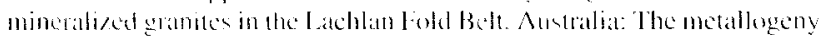

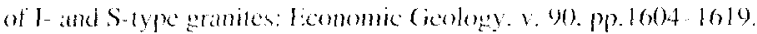

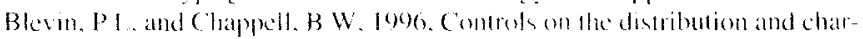

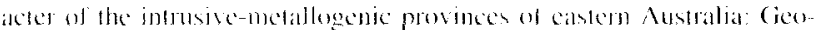

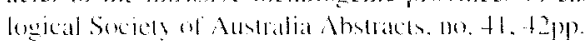

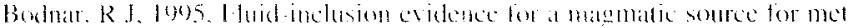

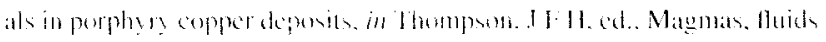

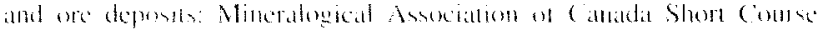
Setien, $1.23,10130152$

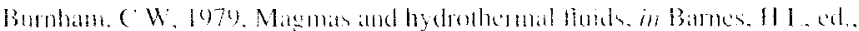

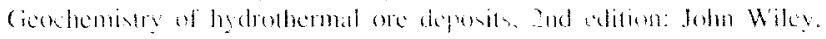
New Yomk. il $71 \quad 130$

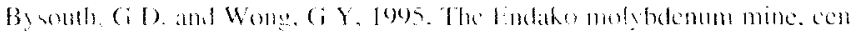

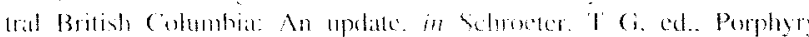

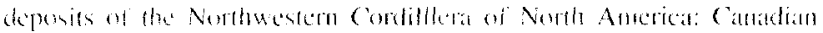

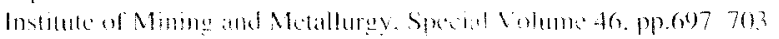

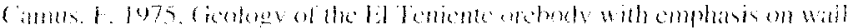

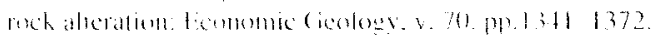

Candela, P A, 1989. Felsic magmats, volatiles and metallogeneris, in What ney. I A, and Naldett. A J.eds. Ore deposits associated with magmas: Reviews in Economic Geology, 1.4, pp. 223 23.3.

Candela, P A. 1991. Physics of aqueous phase exsolution in plutonic enviromments: American Mincralogist. v. 76. p . $1081-1091$

Candela, P A. and Piccoli, P M. 1995, Model oremetal partitioning from melts into vapor/brine mixtures, in Thompson. IF H, ed.. Matymas, Muids and ore deposits: Mineralogical Arsociation of Canada Short Course Series, v. 23, pp. 101127

Carten, R B, Walker, B M, Geraghy, E P. and Gunow, A J. 1988. Compari. son of field-bated studies of the Henderson porphyry molybdenum deposit with experimental theoretical models of porphyry systems. in Taylor, R P. and Strong. D F, eds., Recent atvances in the geolngy of granite-related mineral deposits: (atadian Institute of Mining and Metallurgy. Special Volume 39 . pp $351-360$.

Carten. R B, White. W H and Stein. H J. 1993. High-grade granite-related molybdenum systems: classilication and origin, in Kirkham, R V. Sinclair. W D). Thorpe. R l. and Duke. J M. eds.. Mineral deposit modelling:

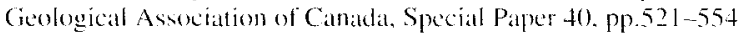

(ermy. P, 1991, Rane-clement granitic pegmatites. Pant II: Regionat on nlobal

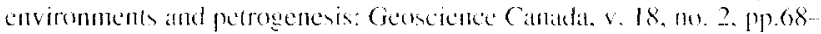
81.

Cline, J S, 1905, Genesi of porphyry copper eleposis: The behavior of water. chloride and copper in erystallizing melts, in Pieree, F W, and Bolm, J G. eds. Porphyry copper deposits ot the American Cordillera: Arizona Cieolonical Socicty Digest 20, pp.69-82.

Collins, W J, Beams, S D, White, A J R and Chappell, B W. 1982, Nature and origin of $\triangle$-type granites with particular teference to southeastern Aus-

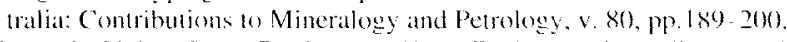

Crepeau. R. Voicu, Giand Bardoux. R. 1996. Geolosy and metalfogeny of the Omai gold mines. Guyana, South America: 39th congresso Brasileiro de Geolocia Salvador Bahial 1996. Anats. v. 7. pp.241-243.

Crouse, R A, Cerny. P. Trueman. P I and Burt, R O. 198t. The fanco pene matite, southasiern Manioba, in Guilled, ( R R and Martin. W. eds., Tho geology of industrial minerals in Candad: Canadian lnstitute of Mining and Metallurgy Special Volume 29 , pp. $160-176$.

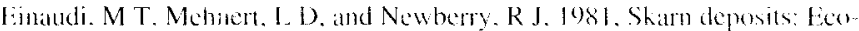
nomic Geology. 75th Anniveratry Volume. pp.317 391.

Emmons. W H, 1927. Relations of metalliferous lode systems to ieneous intrusions: Thansdetions of the American Institute of Mining and Metal furgical Enginecrs, v. 74, pp.29 .70.

Geijer. P. 1960). The Kiruna ores. in Guide to Exctusions A27 and C22 Part 1 (Sweden): 21 st international Cieological Congress, Nonden. 1960. pl $.24-3 x$.

Goelnicht. N M. Groves, D I. McNanghton. N J. and Dimo, (3. 1989. An epigenetic origin for the Telfer gold deposit. Western Australia. in Kätys, $R$ R. Ramsay, W R H. and Goves, D I. eds. The geology of gold deporits: the persective in 1988: Economic Geokey Monograph 6. po 151167.

Gustifison. I. B and Hunt. J P. 1975. The porphyry copper depenil at Li Sal vador, Chile: Lcomomic Geology. 1.70 . pp.857 912

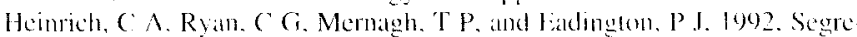
gation of ore metak between maematic brine and vapor a a fluid inclu-

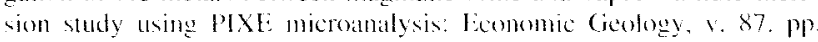
$1.560-1.583$

Hitzman. M W, Onstes. N. and Einated, M T, 1902. Cicological chatacteris-

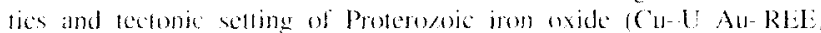
deposits: Precambrian Research. v. 58, pp. $241 \ldots 287$

Hothe. M A, Hobe, A C. Costi. H C, and Tersedra I T, 1991, Geonemical characteristics of crvolite-lin-bearing grantes from the pitinga mine. northwestem Brat a review: Journal of Gerchemical Exploration. $v$ 40. 00.227249

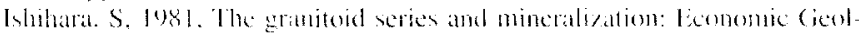
ogy. 75a Anniversary Volume, pp. $458-484$.

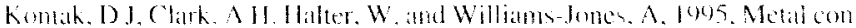

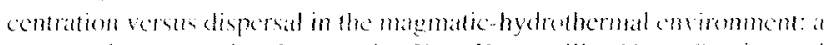

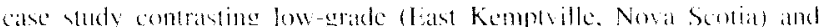

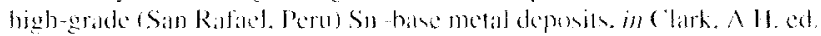

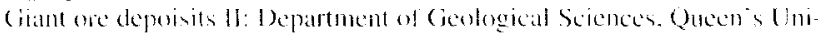
versily. Kingstom. pp. . $47-413$.

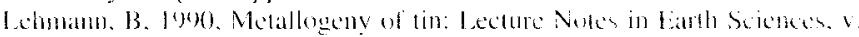
i2. Springer Vorlay. Borlin. 2l lpe

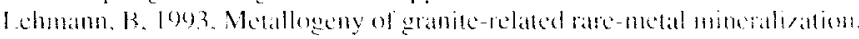

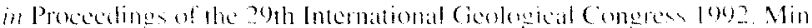

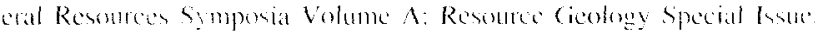
mo. 15. Pp. 35. 30 ?

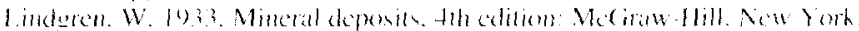
() $30 \mathrm{pr}$ ? 
Mao, J, Chen, Y, Bi, C, and Li, H, 1995, Geology of tin deposits in China: Scientia Geologica Sinica, v. 4, pp.121-177.

MacDonald, G D, and Arnold, L C, 1994, Geological and geochemical zoning of the Grasberg igneous complex, Irian Jaya, Indonesia: Journal of Geochemical Exploration, v. 50, pp.143-178.

McInnes, B I A, and Cameron, E M, 1994, Carbonated, alkaline hybridizing melts from a sub-arc environment: mantle wedge samples from the Tabar-Lihir-Tanga-Feni arc, Papua New Guinea: Earth and Planetary Science Letters, v. 122, pp.125-141.

Megaw, P K M, 1986, Geology and geologic history of the Santa Eulalia mining district, Chihuahua, Mexico, in Clark, K F, Megaw, P K M and Ruiz, J, eds, Lead-zinc-silver carbonate-hosted deposits of Northern Mexico: University of Texas, El Paso, Society of Economic Geologists Guidebook, pp.213-232.

Meinert, L D, 1993, Igneous petrogenesis and skarn deposits, in Kirkham, R V, Sinclair, W D, Thorpe, R I, and Duke, J M, eds., Mineral deposit modelling: Geological Association of Canada, Special Paper 40, pp.569-583.

Newcrest Mining Staff, 1996, The Cadia 'wallrock-porphyry'-style goldcopper deposit, NSW, in Porphyry related copper and gold deposits of the Asia and Pacific Region: Australian Mineral Foundation, Glenside, South Australia, pp.16.1-16.10.

Partington, G A, McNaughton, N J, and Williams, I S, 1995, A review of the geology, mineralization and geochronology of the Greenbushes pegmatite, Western Australia: Economic Geology, v. 90, p.616-635.

Patterson, D J, Ohmoto, H, and Solomon, M, 1981, Geologic setting and genesis of cassiterite-sulfide mineralization at Renison Bell, western Tasmania: Economic Geology, v. 76, pp.393-438.

Pei, R, and Hong, D, 1995, The granites of south China and their metallogeny: Episodes, v. 18, nos. 1 \& 2, pp.77-82.

Pollard, P J, Geology of rare metal deposits: an introduction and overview: Economic Geology, v. 90, pp.489-494.

Polya, D, 1989, Chemistry of the main-stage ore-forming fluids of the Panasqueira W-Cu(Ag)-Sn deposit, Portugal: implications for models of ore genesis: Economic Geology, v. 84, pp.1134-1152.

Reeve, J S, Cross, K C, Smith, R N, and Oreskes, N, 1990, Olympic Dam copper-uranium-gold-silver deposit, in Hughes, F E, ed., Geology of the mineral deposits of Australia and Papua New Guinea, v. 2: Australasian Institute of Mining and Metallurgy Monograph, no 14, pp.1009-1035.

Richards, J P, and Kerrich, R, 1993, The Porgera gold mine, Papua New Guinea: Magmatic hydrothermal to epithermal evolution of an alkalictype precious metal deposit: Economic Geology, v. 88, pp.1017-1052.

Roedder, E, 1984, Fluid inclusions: Reviews in Mineralogy, v. 12, 644pp.

Rundquist, D V, 1982, Zoning of metallization asociated with acid magmatism, in Evans, A M, ed., Metallization associated with acid magmatism: John Wiley, Chichester, pp.279-289.

Sakurai, W, and Shimazaki, H, 1993, Exploration of blind skarn deposits based on the mineralization model of the Kamioka mine, Gifu prefecture, central Japan: Proceedings of the 29th International Geological Congress 1992. Mineral Resources Symposia Volume B: Resource Geology Special Issue, no. 16, pp.141-150.

Sawkins, F J, 1990, Metal deposits in relation to plate tectonics, 2nd edition: Springer-Verlag, Berlin, 461pp.

Schuppen, W, Büder, W, and Lange, G, 1994, On uranium mineralization in the vein deposits of the western Erzgebirge, Germany, in von Gehlen, K and Klemm, D D, eds., Mineral deposits of the Erzegebirge/Krusnéhory (Germany/Czech Republic): Monograph Series on Mineral Deposits, no. 31, Gebrüder Borntraeger, Berlin, pp. 191-207.

Serrano, L, Vargas, R, Stambuk, V, Aguilar, C, Galeb, M, Holmgren, C, Contreras, A, Godoy, S, Vela, I, Skewes, M A, and Stern, C R, 1996, The late Miocene to early Pliocene Río Blanco-Los Bronces copper deposit, central Chilean Andes, in Camus, F, Sillitoe, R H, and Petersen, R, eds, Andean copper deposits: new discoveries, mineralization styles and metallogeny: Society of Economic Geologists Special Publication, no. 5, pp.119-130.
Sillitoe, R H, 1985, Ore-related breccias in volcanoplutonic arcs: Economic Geology, v. 80, pp.1467-1514.

Sillitoe, R H, 1991, Intrusion-related gold deposits, in Foster, R P, ed., Metallogeny and exploration of gold: Blackie, Glasgow, pp.165-209.

Sillitoe, R H, 1993, Gold-rich porphyry copper deposits: Geological model and exploration implications, in Kirkham, R V, Sinclair, W D, Thorpe, R I, and Duke, J M, eds., Mineral deposit modeling: Geological Association of Canada, Special Paper 40, pp.465-478.

Sillitoe, R H, 1995, Influence of magmatic-hydrothermal models on exploration strategies for volcano-plutonic arcs, in Thompson, J F H, ed., Magmas, fluids and ore deposits: Mineralogical Society of Canada Short Course Series, v. 26, pp.511-525.

Sillitoe, R H, Halls, C, and Grant, J N, 1975, Porphyry tin deposits in Bolivia: Economic Geology, v. 70, pp.913-927.

Symons, P M, Anderson, G, Beard, T J, Hamilton, L M, Reynolds, G D, Robinson, J M, Staley, R W, and Thompson C M, 1990, Boddington gold deposit, in Hughes, F E, ed., Geology of the mineral deposits of Australia and Papua New Guinea, v. 1: Australasian Institute of Mining and Metallurgy Monograph, no. 14, pp.165-169.

Taylor, H P Jr, 1979, Oxygen and hydrogen isotope relationships in hydrothermal mineral deposits, in Barnes, H L, ed., Geochemistry of hydrothermal ore deposits, 2nd edition: John Wiley, New York, pp.236-277.

Thompson, J F H, Mortensen, J K, and Lang, J R, 1995. Magma suites and metallogeny - examples from the Canadian Cordillera: Pacrim Congress 1995, Auckland, Proceedings, pp.569-574.

Thomson, B, Aftalion, M, McIntyre, R M, and Rice, C, 1995, Geochronology and tectonic setting of silicic dike swarms and related silver mineralization at Candelaria, western Nevada: Economic Geology, v. 90 , pp. $2182-2196$

Vila, T, and Sillitoe, R H, 1991, Gold-rich porphyry systems in the Maricunga belt, northern Chile: Economic Geology, v. 86, pp.1238-1260.

Whitehead, W L, 1919, The veins of Chañarcillo, Chile: Economic Geology, v. 14, pp.1-45.

Williams, P J, Adshead, N D, Blake, K L, de Jong, G, Mark, K, and Rotherham, J F, 1995, Magnetite-Cu-Au deposits in deeply eroded magmatic arcs: lessons from Proterozoic terrains: Pacific Rim Congress 1995 , Auckland, Proceedings, pp.631-636.

Wu, Y, and Mei, Y, 1982, Multi-phase intrusion and multi-phase mineralization and their evolution in Xihuashan tungsten ore field, in Hepworth, J V and $\mathrm{Yu}, \mathrm{H} \mathrm{Z}$, eds., Symposium on tungsten geology, Jiangxi, China, 1981: ESCAP-RMRDC, Bandung, pp.437-449.

Xie, K, Shi, X, and Song, F, 1996, The origin of iron-copper deposit in Marcona mining area, Peru, in Geology and Mineral Resources Proceedings of Ministry of Metallurgical Industry: International Academic Publishers, Beijing, pp.49-53.

Richard H Sillitoe is an independent geological consultant specialising in ore deposits associated with felsic magmatism. His assignments, in more than 70 countries worldwide, have emphasised $\mathrm{Au}$ and $\mathrm{Cu}$ systems, but also have included work on $\mathrm{Mo}, \mathrm{Zn}-\mathrm{Pb}, \mathrm{Ag}$ and $\mathrm{Sn}$ mineralisation.

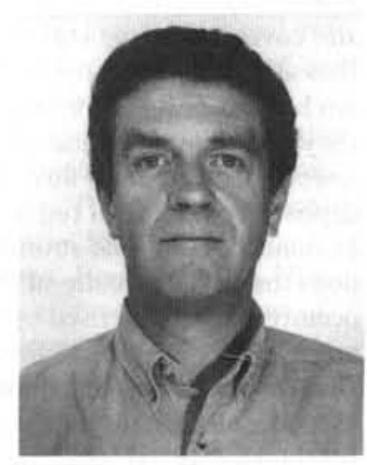

